\title{
Analysis of Business English Professional with the Combination of Training Mode
}

\author{
Taking Xingtai College of Business English Major As Case
}

\author{
Xuejing Li \\ Xingtai University \\ Xingtai,China
}

\author{
Yunman Liu \\ Xingtai University \\ Xingtai,China
}

\begin{abstract}
The Business English majors are starting to exist as an independent discipline, it develops business English training model to meet the requirements of social development that is very important. Based on the needs, the analysis of business English talent Xingtai research and training objectives for the College of Business English Talents Xingtai is not clear with unreasonable curriculum, teachers' imbalance and other issues. Business English training of personnel should be clear objectives, optimization of the curriculum to develop a "double role" teacher, establish training base, thereby enhancing the careers of English graduates capacity to meet the demand for business English talent.
\end{abstract}

Keywords- Business English; Training Objectives; Curriculum; "Double Role" Teacher

\section{INTRODUCTION}

We should conform to the current depth of the world economic, political, cultural and other exchanges and cooperation in all aspects. And our professional business English training model must strive to practice the Ministry of Education, "Eleventh Five-Year Plan" requirements, promote the Combination of Business English Talents training mode. It should explore the development of vocational education to adapt to business English model with Chinese characteristics, develop rapid export-oriented economic development, training in various enterprises and institutions of foreign economic relations, trade, tourism, foreign affairs and other sectors of interpretation, translation work, and management, secretarial, economic and trade public English teaching job. Especially business English professional personnel training is in order to improve the quality and enhance the strength of running, it is necessary to restrict the core issue for the Reform and Development of Business English, and vigorously to strengthen business English professional training model innovation, training high-quality applicationoriented, innovation talents.

\section{SituATION OF BUSINESS ENGLish TALENTS AND PROBLEMS}

After the 1970s, Western countries began to focus on training and teaching business English training applied talents. BBC in1972 published in Business English textbook series expressly stated that its focus is on English listening training business environment, speaking, reading, writing, translation and other interpersonal skills. The ultimate aim is to use business English language and language teaching to achieve a certain goal with a certain occupation, industry linked to that gain the ability to engage in a business environment under foreign occupation. In the course of the business English training professionals, we must construct certain scenarios, social and cultural background; we can give full play to the students by the combination of initiative, enthusiasm and creativity, access to authentic business scenarios or linguistic background. Business English professional training system, to focus on the practical aspects, to make the learners under the given conditions, language skills and business skills are improved. In recent years, foreign scholars specializing in business English training model combine the knowledge and learners who have access to research and development capacity of trying to cultivate high-quality international compound talents. The British Open University Business English Major is in the professional quality of all aspects of student kind of ability to make a more specific and more comprehensive requirements. These countries for business English majors put forward higher requirements for training to enable students to receive English listening, speaking, reading, writing, translation and other aspects of well trained. They are to master English country profiles related to language and literature, politics, economy multifaceted theoretical knowledge management, social and cultural, but also allow students to go to other countries such as China, Russia, Japan training. They strive to cultivate a full range of qualified professional personnel.

In China, with the development of the changing times, there is an increasing social demand, the economy is expected to continue to improve the effectiveness, business English professional use English as a branch of the progressive development and attention. Under the new situation, we should seriously consider the status quo in Xingtai College of Business English Talents and actively explore new directions. Xingtai College is open for business English training earlier in Hebei University, teaching a foreign language department and entities were the Ministry of International Educational Exchange (Sino-foreign cooperative professional). English students mainly study the basic theory and basic knowledge of foreign languages and applied linguistics, foreign literature, science and technology and other aspects of English. Sino-foreign cooperative business English program aims at training with international standards, with strong English listening, speaking, reading and writing skills, to master the system theory and working 
knowledge of international business and foreign-funded enterprises have engaged in foreign business practices composite application capabilities talent. Currently, the terms of the school of Business English Talents mainly the following questions:

\section{A. Training Objectives Are Not Clear.}

Xingtai College Foreign Language Department since 1983 inception, its training objectives has been to the traditional English-language base that aims to develop a solid language foundation with strong language integrated application capabilities, a broad range of knowledge. So that they can skillfully use English in education, trade, agricultural science and technology, culture, tourism, foreign enterprises and foreign affairs and other departments engaged in the application, complex high-level expertise teaching, translation, research, management, cultural and other work. With economic globalization and the accelerating pace of internationalization of trade, the demand for more specialized talent increase. Companies need specialized personnel aspects of Business English, and knowledge of traditional English major students in English language and literature-based, lack of business knowledge and fragmented, rigid structure and social needs of students' knowledge are seriously out of line.

\section{B. Teaching System and Curriculum Are Unreasonable.}

Under the guidance of traditional training objectives, the Department of Foreign Languages current teaching system and the curriculum are still the main English language and literature, main courses, including basic English, advanced English, English reading, listening, spoken English, English grammar, English translation and English writing, English and American Literature, Linguistics, English teaching, English translation. With the development and needs of the situation, it opened a business English elective courses, including theory and practice of international trade, foreign correspondence, business communication, reading newspapers and trade, economic interpretation, these programs accounted for about $20 \%$ of the total credits of professional courses. Business English teaching is mainly focused on imparting business knowledge, and the total number of hours are less than normal, leading students to acquire knowledge systematic, complete, plus the lack of opportunity to practice business skills of students do not get training, far from being able to meet the community business English talent requirements.

\section{Faculty Is Uneven.}

Business English is an emerging discipline, which includes two areas of language and business that is related to linguistics, intercultural communication, economics, management, education and other cross-disciplinary. New discipline for teachers presented new challenges. Business English professional teachers both have solid English language skills, are able to teach students English language knowledge and skills, but also have business knowledge systems and the wealth of business experience.
Sino-foreign cooperative business English majors curriculum includes many business basics, after graduation they may be suitable in a variety of foreign economic and trade enterprises, foreign-invested enterprises, foreign embassies and business organizations as well as all types of business entities engaged in business secretary, business assistant, assistant sales manager and translator, sales representatives and general managers work.

However, the current College of Foreign Languages Department of English Xingtai has total number of 78 professional teachers, of whom the vast majority of teachers are professional English language or English literature graduate, they lack of a business background, but also the lack of use of practical work experience in business English. They can provide some guidance to the students in the English language, but in many professional business issues, such as inquiry, payment, shipping, business presentations and other aspects they are difficult to meet the needs of students. This faculty is very uneven, far from meeting the needs of business English teaching.

\section{Students Have Less Opportunity to Practice and Adequate Training.}

English majors have fewer opportunities to practice; time is short, so that students' English proficiency gets plenty of exercise. Lack of effective communication between schools and businesses and long-term cooperation is resulting in students who rarely have the opportunity to trade, foreign, private and other units to practice, they does not implement an effective interface between the out of school and embark on jobs. On the one hand, the demand for business English talent is increasing; on the other hand, English majors' employment situation is not optimistic. University trained a lot of English professional talent, but really need to post in English language or literature but it is rare.

\section{Business ENGLISH DEVELOPMENT PROSPECTS}

Xingtai status quo need business English language skills, the employer there are two different views, one view Xingtai Business English talent is already saturated, while another view was that it is still very lacking. But the overall look of high-quality, high-level business English talent should still very be lacking, because a considerable part of employers believe they will accept graduates in recent years business English direction. Due to recent rapid growth in the number of foreign Xingtai area, along with China's international status as well as the recovery continues to strengthen the overall financial environment, foreign trade will continue to increase, but also means that the competition will be in the next business English talent very intense. Therefore, a student with good English language skills and solid business knowledge and skills of highly qualified business English talent still has great development prospects and space. This is for us to Run Business English to provide the necessary assurance. 


\section{THE CHARACTERISTICS OF TRAINING MODE IN COMBINING BUSINESS ENGLISH IMPROVEMENT AND RESEARCH PERSONNEL TRAINING PROGRAM}

From our survey, despite the community's current professional standards and the ability to work, Business English students are recognized; it provides us with the following improvements:

We should train a group of complex teachers. To train students in the compound must establish a composite team of teachers. The academic knowledge of learning and language teaching combine to help students learn discipline system knowledge and inherent logic, learn to use decent language to express this knowledge and intrinsic logic, in improving the standard of teaching teachers to improve the level of scientific research. A long-term task can meet the needs of the times and their own development.

We should strengthen Teaching Management. To train high-quality business English talent, we must have the appropriate supporting personnel training measures to develop training programs that meet the social needs of personnel, as well as the necessary teaching materials, teaching methods and models to further improve the improvements. We should introduce the advanced teaching philosophy and guide them to the knowledge into practice business English skills.

"Combination" is to learn to work together with the mode of education; body includes students, businesses, and schools. This model is based on employment-oriented and full use of the school as well as the different educational environments and resources to classroom teaching-oriented school education, and direct access to the actual experience of the combination of outside work, throughout the training process among students.

\section{V. "COMBINATION" STRATEgY UNDER THE MODE OF BUSINESS ENGLISH TALENTS}

From the survey results, ideal for business English talent training mode should be consistent with the "language + business knowledge + Business Skills" model, this model through training of personnel is to meet the demand for business English talent. Business English training plan should include three sections, namely, English language courses, basic courses in Business English courses and business basics. Improving their language proficiency is always the basic purpose of business English teaching, and therefore we should provide students with more opportunities for relevant language skills to improve language skills while also improving students' critical thinking skills. On the other hand, we must also enhance students' ability to use business skills, the creation of business English, business English interpreter, business English writing, business documents and other courses that allow students to learn in a real than the real business environment by engaging in business English related activities. In the third sector, business expertise should enhance learning courses. We should have introduction to Business Studies courses that can be opened on the basis of the stage, so that students early can exposure to the business knowledge and business activities. After entering the professional learning stage, we should provide students with a broader business knowledge platform, open international trade practice, introduction to economics, international commercial law, international finance, international business courses practical operation, to lay a solid foundation. And they learn English the expression that describes the knowledge, so that students of business knowledge with business skills training are more comprehensive, systematic, at work they can cope with business activities in different fields, which fully embodies the characteristics of the application type, compound talents.

\section{CONCLUSIONS}

Practice teaching business English teaching is an important part, but also the necessary means and skills of the students' practical training. Students may exercise all aspects of capacity through practice, raise awareness of the work. Schools should provide students the opportunity to create more business practices, as soon as possible so that students can learn the ability to convert knowledge and practice, learn to identify and solve problems, encourage students to participate in various forms of teaching practice, broaden horizons.

\section{References:}

[1] Lei Chunlin. International Business Research on Language Teaching Content-based business [J]., 2006, (1).

[2] Liao Guoqiang. Business English discipline development and talent cultivation research [Z]. Seventh National Symposium on International Business English, Foreign Economic and Trade University Press, 2006, (8).Negative factors and countermeasures

[3] Dai Xiangchao. Impact Business English professional training mode effects [J]. Hunan Medical University (Social Sciences), 2008 (5).

[4] Li Yanmin. Preliminary training mode reform in the service economy as the core business English talent [J]. Market Modernization, 2008, (19).

[5] Huang Yunlin, Chen Yu. English Business English Course System [J]. Chongqing University, 2005, (4). 